\title{
THE EFFECT OF THREE PRETREATMENTS ON BREAKING SEED DORMANCY OF BAOBAB (ADANSONIA DIGITATA L.)
}

\author{
BASHIR KA*, MUSA DD, BISHIR R \\ Department of Biological Sciences, Faculty of Life Science, Federal University Dutsin-Ma, P.M.B 5001, Dutsin-ma, Katsina State, Nigeria. \\ Email: abdoolkut12@gmail.com
}

Received: 11 January 2021, Revised and Accepted: 05 April 2021

\section{ABSTRACT}

Objective: Baobab (Adansonia digitata) is a native tree that is found in African savannas, it is a member of family 'Malvaceae'. The tree is found in Nigeria, South Africa, Botswana, Namibia, Mozambique and in different regions of western Madagascar. Seed dormancy is the most limiting factor for some plants propagation. Dormancy allows seeds to separate from their mother plant and survive dispersal, over distance, and time before growth recommences. This study was aimed to determine the effect of three pre-treatments on breaking the seed dormancy of Adansonia digitata L., a multipurpose and indigenously endangered tree.

Methods: The study was carried out in the greenhouse of the Department of Biological Sciences, Federal University Dutsin-Ma, Nigeria. The three pretreatments are: Soaking in hot water $\left(100^{\circ} \mathrm{C}\right)$ for $5,10,15$, and $20 \mathrm{~min}$; and soaking in sulfuric acid $\left(\mathrm{H}_{2} \mathrm{SO}_{4}\right)$ and hydrochloric acid (HCL) concentrations $(100 \%, 75 \%, 50 \%$, and $25 \%)$ for 5, 10, 15, and $20 \mathrm{~min}$. Untreated seeds served as control. These were laid out in a complete randomized design with three replications. Data were collected on germination percentage, germination rate, day of emergence, and the average seedlings height.

Results: The result showed that earliest mean days of emergence (7 days) were observed in seeds subjected to hot water treatment at 15 min. It also showed the highest rate of germination and percentage $6(100 \%)$. On the other hand, the effect of acids $\left(\mathrm{H}_{2} \mathrm{SO}_{4}\right.$ and $\left.\mathrm{HCL}\right)$ pre-treatments on the seeds gave a fair result (16.66-33.33\%), untreated seeds did not germinate.

Conclusion: All the pre-treatments used in the study were found to be effective. However, soaking of seeds in hot water $\left(100^{\circ} \mathrm{C}\right)$ pre-treatment for 15 min is recommended for breaking the seed dormancy of A. digitata.

Keywords: Baobab, Breaking, Dormancy, Hydrochloric acid, Hot water, Sulfuric acid.

(C) 2021 The Authors. Published by Innovare Academic Sciences Pvt Ltd. This is an open access article under the CC BY license (http://creativecommons. org/licenses/by/4.0/) DOI: http://dx.doi.org/10.22159/ijags.2021v9i3.40759. Journal homepage: https://innovareacademics.in/journals/index.php/ijags

\section{INTRODUCTION}

Adansonia digitata is a native deciduous tree of African savannas and belongs to the family Malvaceae. It is called by several local names in central Africa as "bu-hibab" (fruit with several seeds) Ibozu, Moana, dead rat tree, Tree of life, etc. The Baobab tree is found in areas of South Africa, Botswana, Namibia, Nigeria, and Mozambique and occurs in semi-arid and sub-humid regions of western Madagascar. The tree can grow up to $25 \mathrm{~m}$ in height, $28 \mathrm{~m}$ in girth and can live for several 100 years [1]. The form of the trunk varies. In young trees, it is conical, in mature trees, it may be cylindrical, bottle shaped or tapering with branching near the base. It has thick, angular, wide spreading branches and a short, stout trunk which attains 10-14 $\mathrm{m}$ or more girth and often becomes deeply fluted. The Baobab tree was named Adansonia to commemorate the French surgeon Michel Adanson (1726-1806); the species name digitata meaning handlike, is in reference to the shape of the leaves. The genus comprises eight species bearing large, nocturnal flowers. A. digitata has high water holding capacity and its hollow trunk keeps the water potable for many years and serves as a reservoir during drought [1]. It is also resistant to fire and survives well in dry climate. The leaves are foliate and are simple during the young stage. Flowers are pendulous, showy, and white. A. digitata has numerous medicinal and non-medicinal uses. Every part of the tree is reported to be very useful. The tree is named as: "The small pharmacy or chemist tree" for the reason that all parts such as the leaves, bark, and fruits, seeds are used as foodstuffs and medicines [1]. It also has numerous health benefits which can be related to the presence of bioactive compounds (terpenes, saponins, tannins, and many more) that are isolated from its various parts such as leaves and fruit. Studies on morphogenetic potential and ability of in vitro cloning of this African resource of great economic value have been undertaken for its preservation and use in reforestation programs.

Seed dormancy is the most limiting factor for some plants propagation. Dormancy allows seeds to separate from their mother plant and survive dispersal, over distance, and time before growth recommences. Seed dormancy is a physiological phenomenon in plants and is more common in wild plants than the crop plants [2]. Seed dormancy is defined as the failure of a viable seed to germinate when conditions are favorable for seed germination. Ecological significance of seed dormancy is that seeds only germinate when conditions are favorable and this ensures plant species survival. Seed germination failure is attributed to the presence of either exogenous or endogenous factors. The endogenous factors could be due to the presence of the hard seed testa (morphological seed dormancy) or germination inhibitors present in the capsules or endosperm [3], while exogenous seed dormancy (outside the embryo) is caused by physiological factors [4]. The main problem encountered in propagating fruit tree crops seedlings for afforestation programs is dormant seeds. There are a number of ways used to improve germination of seeds in which various seed priming techniques have been developed, including hydro priming (soaking seeds in water), halo priming (soaking seeds in inorganic salts solution), osmo priming (soaking in solutions of different organic osmotic potentials), thermo priming (treatment of seeds with low or high temperatures), solid matrix priming (treatment of seed with solid matrices), and bio priming (hydration using biological compounds) [5]. Biological diversity for tree species is now becoming priority; hence, robust germ plasm conservation programs are needed. According to Akinnifesi et al. [6], lack of uniform and rapid seed germination in tree crops at suitable conditions imposes problem on seed researchers, botanists, and farmers. 
The seeds of $A$. digitata have a very hard and impermeable seed coat that prevents the entry of water, nutrients, and oxygen. This together with the actions of man and animals made baobab to become critically endangered which will in the future lead to its extinction. The seeds also do not germinate immediately on their own accord due to dormancy imposed by hard seed coat [7]; therefore, dormancy must be broken before germination can occur [8]. Little research has been carried out on the effectiveness of sulfuric acid $\left(\mathrm{H}_{2} \mathrm{SO}_{4}\right)$, hydrochloric acid (HCL), and hot water pre-treatments on breaking the seed dormancy of $A$. digitata. This research work was aimed to determine the methods of breaking seed dormancy in A. digitate and to determine the effects of three pretreatments on breaking the seed dormancy of $A$. digitata.

\section{METHODS}

\section{Experimental site}

The experiment was conducted within the screen house of the biological garden of the Department of Biological Sciences, Federal University Dutsin-ma. Dutsin-ma is a town situated in Katsina State, Nigeria. Its geographical coordinates are $12^{\circ} 27^{\prime} 18^{\prime \prime}$ North, $7^{\circ} 29^{\prime} 29^{\prime \prime}$ East with an elevation of 605 meters above the sea level.

\section{Seed collection}

A. digitata fruit pulps were sourced from bushes and neighboring villages, in Dutsin-ma local government area of Katsina State under matured trees of the species between February and March 2018. The seeds were isolated from the fruit pulp and washed with tap water to remove the white powder surrounding them. The seeds were tested for viability using flotation method; in which the seeds that float in water after $24 \mathrm{~h}$ of soaking were discarded as unviable and the viable ones were left to dry. These viable seeds were stored at ambient temperature $\left(28^{\circ} \mathrm{C}\right)$ until their use.

\section{Seed treatment}

Seeds were subjected to physical and chemical scarification. Physical scarification was performed through soaking the seeds in hot water $\left(100^{\circ} \mathrm{C}\right)$, whereas chemical scarifications were carried out by immersing the seeds in different concentrations of $\mathrm{H}_{2} \mathrm{SO}_{4}$ and $\mathrm{HCL}$ at different times.

\section{Hot water treatment}

This trail was conducted to assess the effects of hot water on the seeds of A. digitata. Water was allowed to boil at $100^{\circ} \mathrm{C}$. Thereafter, a total of 24 seeds were soaked in boiled water for four different times $(5 \mathrm{~min}$, $10 \mathrm{~min}, 15 \mathrm{~min}$, and $20 \mathrm{~min}$ ) after soaking the seeds were left to air dry.

\section{$\mathrm{H}_{2} \mathrm{SO}_{4}$ treatment}

This trial was conducted to assess the effects of different soaking time and different concentration levels of $\mathrm{H}_{2} \mathrm{SO}_{4}$ on breaking the seed dormancy of $A$. digitata. A total of 24 seeds were respectively soaked in four $\mathrm{H}_{2} \mathrm{SO}_{4}$ concentrations $(100 \%, 75 \%, 50 \%$, and $25 \%)$ for $5,10,15$, and $20 \mathrm{~min}$. After soaking, the seeds were removed, washed, and rinsed in running tap water to remove any remaining acid and finally air dried before sowing for germination $[9,10]$.

\section{HCL treatment}

This trial was conducted to assess the effects of different soaking time and different concentration levels of $\mathrm{H}_{2} \mathrm{SO}_{4}$ on breaking the seed dormancy of $A$. digitata. A total of 24 seeds were immersed in four HCL concentrations $(100 \%, 75 \%, 50 \%$, and $25 \%)$ for $5,10,15$, and $20 \mathrm{~min}$. After soaking, the seeds were removed, washed, and rinsed in running tap water to remove any remaining acid and finally air dried before sowing for germination $[9,10]$

\section{Control treatment}

For control, the seeds were not treated with acids or hot water. It was carried out to compare the effect of no pre-treatment on breaking the seed dormancy of $A$. digitata.
Experimental design and data collection

The experiment was carried out in completely randomized design, which involved three treatments (Hot water, $\mathrm{H}_{2} \mathrm{SO}_{4}$, and $\mathrm{HCL}$ ) and control. Germination was monitored daily and recorded from the day of sowing by counting the number of germinated seeds. Germination was allowed to proceed for 42 days ( 6 weeks) after which the experiment was terminated. Seeds were considered germinated when the healthy, white radical had emerged through the integument. Germination parameters assessed in the course of the experiment include: Days of Emergence (Numbers of days taken for first emergence), rate of germination (Numbers of seeds germinated), GP, and the average seedling height.

$$
\text { Germination percentage }(\mathrm{GP})=\frac{\text { Number of germinated seeds }}{\text { Number of tested seeds }} \times 100
$$

\section{RESULTS}

\section{Effect of hot water pre-treatment}

Seed germination under the different hot water treatments gave the highest GP (66.66-100\%). On the other hand, seeds were subjected to 5 and 10 min hot water pre-treatment, and gave a fair GP of $66.66 \%$. The seedlings commenced germination on the $7^{\text {th }}, 8^{\text {th }}$, and $9^{\text {th }}$ days after sowing, attaining an average height of 31-36 cm. In general, there was no germination under control (Table 1).

\section{Effects of $\mathrm{H}_{2} \mathrm{SO}_{4}$ pre-treatment}

Under $\mathrm{H}_{2} \mathrm{SO}_{4}$ pre-treatment, low GP of (16.66-33.33\%) across all the treatment time and concentration level, while the shortest germination commencement period was 8 days at the $100 \%$ and $75 \%$ concentration

Table 1: Germination of Adansonia digitata seeds in hot water $\left(100^{\circ} \mathrm{C}\right)$ treatment

\begin{tabular}{lllll}
\hline Pre-treatments (min) & DOE & GR & GP (\%) & ASH (cm) \\
\hline 5 & 8 & 4 & 66.66 & 36 \\
10 & 9 & 4 & 66.66 & 31 \\
15 & 7 & 6 & 100.00 & 36 \\
20 & 9 & 5 & 83.33 & 36 \\
Control & 0.0 & 0.0 & 0.00 & 0.00 \\
\hline
\end{tabular}

DOE: Day of emergence, GR: Germination rate, GP: Germination percentage, ASH: Average seedlings height

Table 2: Germination of Adansonia digitata seeds in sulfuric acid $\left(\mathrm{H}_{2} \mathrm{SO}_{4}\right)$ treatment

\begin{tabular}{llllll}
\hline $\begin{array}{l}\text { Treatment } \\
\text { (min) }\end{array}$ & $\begin{array}{l}\text { Acid } \\
\text { concentrations(\%) }\end{array}$ & DOE & GR & $\begin{array}{l}\text { GP } \\
(\%)\end{array}$ & $\begin{array}{l}\text { ASH } \\
(\mathbf{c m})\end{array}$ \\
\hline 5 & 100 & 0.0 & 0.0 & 0.00 & 0.00 \\
10 & 75 & 8 & 2 & 33.33 & 35 \\
15 & 50 & 12 & 1 & 16.66 & 35 \\
20 & 25 & 40 & 1 & 16.66 & 5 \\
Control & 0.0 & 0.0 & 0.00 & 0.00 & 0.00 \\
\hline
\end{tabular}

DOE: Day of emergence, GR: Germination rate, GP: Germination percentage, ASH: Average seedlings height

Table 3: Germination of Adansonia digitata seeds in hydrochloric acid (HCL) treatments

\begin{tabular}{llllll}
\hline $\begin{array}{l}\text { Treatment } \\
\text { time (min) }\end{array}$ & $\begin{array}{l}\text { Acid } \\
\text { concentrations (\%) }\end{array}$ & DOE & GR & $\begin{array}{l}\text { GP } \\
\mathbf{( \% )}\end{array}$ & $\begin{array}{l}\text { ASH } \\
(\mathbf{c m})\end{array}$ \\
\hline 5 & 100 & 0.0 & 0.0 & 0.00 & 0.00 \\
10 & 75 & 24 & 1 & 16.66 & 30 \\
15 & 50 & 34 & 1 & 16.66 & 24 \\
20 & 25 & 42 & 1 & 16.66 & 4 \\
Control & 0.0 & 0.0 & 0.0 & 0.00 & 0.00 \\
\hline
\end{tabular}

DOE: Day of emergence, GR: Germination rate, GP: Germination percentage, ASH: Average seedlings height 
levels for 5 and $10 \mathrm{~min}$, was recorded. Meanwhile, seeds pre-treated at $25 \%$ conc. for $20 \mathrm{~min}$ took longer period (40 days) to start germinating Average seedling height in all the treatments was between 5 and $35 \mathrm{~cm}$ (Table 2).

\section{Effects of HCL pre-treatment}

When compared with hot water and $\mathrm{H}_{2} \mathrm{SO}_{4}$ pretreatments, HCL prepretreatments were not faster as the seeds commenced germination from 24 to 42 days after sowing. Fair GP of $33.33 \%$ was recorded in seeds pretreated at $100 \%$ HCL for $5 \mathrm{~min}$, while the rest produced a least percentage of $16.66 \%$ as indicated in Table 3 .

\section{DISCUSSION}

In this study, all pretreatments significantly affected the various germination parameters (day of emergence, germination rate [GR], GP, and average seedlings height). The study revealed that hot water pre-treatment germinated better and faster compared to other pretreatment. Untreated seeds (control) did not germinate at all. Seeds germination in hot water for 15 min emerged earlier (7 days after sowing), gave the highest GR and percentage 6 (100\%), followed by similar treatment in $20 \mathrm{~min} 5$ (83.33). This was in conformity with the work carried out on A. digitata by Besco et al. [11] who reported that hot water pre-treatment provided the best results when compared with other treatments. However, Amusa [12] opined that, subjecting the seeds to hot water could lead to the seed embryo been killed because of prolonged contact with boiled water. This was also contrary to the view of Yagoub [13], who offered that pretreatment of $A$. digitata seeds in hot water for $10 \mathrm{~min}$, increased its growth potential. Furthermore, seeds soaked in hot water for 10 min gave a fair GP of $67 \%$. The fact that hot water yielded highest germination values within shortest time indicates that the more rapidly the seed coat is ruptured, the faster the rate of germination. In terms of seedling height, an average of 31-36 was recorded in seeds treated with hot water. This was significant when compared to acids treatments.

$\mathrm{H}_{2} \mathrm{SO}_{4}$ pre-treatment closely followed hot water treatment by emerging early (8-12 days) after sowing even though, it gave a low GR and GP. Lower $\mathrm{PG}$ recorded in $\mathrm{H}_{2} \mathrm{SO}_{4}$ acid treatments at 5 and $15 \mathrm{~min}$ on A. digitata could be due to the damage caused to the embryo by the $\mathrm{H}_{2} \mathrm{SO}_{4}$ chemical. This is in conformity with the findings of Arama et al. [14]. Aref et al. [15] who claimed that $A$. digitata seed emergence was improved by several pre-sowing methods and durations.

Compared to hot water pretreatment when compared among the three pretreatments, seeds immersed in different HCL concentrations at different time interval gave a very low GR and percentage. It was observed that HCL treatment was not found to be suitable in improving germination of $A$. digitata. Lack of germination in seeds pre-treated with $100 \%$ concentrated $\mathrm{HCL}$ and $\mathrm{H}_{2} \mathrm{SO}_{4}$ indicates that the high acid concentration had killed the embryo.

\section{CONCLUSION}

All the pretreatments were found to be effective in breaking the seed dormancy of $A$. digitata. However, hot water pre-treatment for $15 \mathrm{~min}$ was the most effective since it gave the highest germination values. Lack of seed germination in untreated seeds (control) indicates that the water has not activate the enzymes that allow the seed to germinate. Based on the findings of this research, soaking of seeds in hot water $\left(100^{\circ} \mathrm{C}\right)$ treatment for $15 \mathrm{~min}$ is, therefore, recommended for breaking the seed dormancy of $A$. digitata. There is need to focus on other faster methods of breaking seed dormancy of $A$. digitata and other plants of economic benefits in the future researches.

\section{REFERENCES}

1. Shukla YN, Dubey S, Jain SP, Kumar, S. Chemistry, biology and uses of Adansonia digitata. A review. J Med Arom Plant Sci 2001;23:429-34

2. Farahani HA, Moaveni P, Maroufi K. Effect of thermopriming on germination of cowpea (Vigna sinensis). Adv Environ Biol 2011;5:1668-73.

3. Hilhorst HW, Groot SP, Bino RJ. The tomato seed as a model system to study seed development and germination. Acta Bot Neerl 2006;47:169-83.

4. Yang QH, Ye WH, Yin XJ. Dormancy and germination of Areca traindra seeds. Sci Hortic 2007;113:107-11.

5. Ashraf M, Foolad MR. Pre-sowing seed treatment: A shot gun approach to improve germination, plant growth and crop yield under saline and non-saline conditions advances in agronomy. Crop Sci 2005;88:241-71.

6. Akinnifesi FK, Sileshi G, Mkonda A, Ajayi OC, Mhango J, Chilanga T. Germplasm supply, propagation and nursery management of Miombo fruit trees. In: Akinnifesi FK, Sileshi G, Ajaji O, Tchoundjeu Z, Matakala P, editors. Indigenous Fruit Trees in the Tropics: Domestication, Utilization and Commercialization. United Kingdom: CABI Publishing Ltd.; 2007.

7. Tal-Dia A, Toure K, Sarr O, Sarr M, Cisse MF, Garnier P, et al. A baobab solution for the prevention and treatment of acute dehydration in infantile diarrhoea. Dakar Med 1997;42:68-73.

8. Bewley JD. Seed germination and dormancy. Plant Cell 1997;9:1055-66.

9. Schelin M, Tigabu M, Eriksson I, Sawadogo L, Ode P. Pre-dispersal seed predation in Acacia macrostachya, its impact on seed viability, and germination responses to scarification and dry heat treatments. J Agron Crop Sci 2004;7:251-67.

10. Wickens GE, Lowe P. The baobabs. In: Pachycauls of Africa, Madagascar and Australia. Berlin, Germany: Springer Science Business Media; 2008

11. Besco E, Braccioli E, Vertuani S, Ziosi P, Brazzo F, Bruni R, et al. The use of photochemiluminescence for the measurement of the integral antioxidant capacity of baobab products. Food Chem 2007;102:1352-6.

12. Amusa TO. Effects of three pre-treatment techniques on dormancy and germination of seeds of Afzelia africana (Sm. Expers). J Hortic Forest 2011;3:96-103

13. Yagoub S. Antimicrobial activity of Tamarindus indica and Adansonia digitata extracts against $E$. coli isolated from urine and water specimens. Resour J Microbiol 2008;3:193-5.

14. Arama E, Michaud P, Rouffiac R, Rodriguez F. A new excipient in pharmaceutical formulation of theophylline tablets of the hydrophilic matrix type: The pulp of the baobab fruit (Adansonia digitata). Farmaco Prat 1988;43:303-15.

15. Aref IM, Ali H, Atta E, Al Shahrani T, Ismail A. Effects of seed pretreatment and seed source on germination of five Acacia spp. Afr J Biotech 2011;10:15901-10. 